\title{
NOTICE TO AUTHORS
}

Latin American Antiquity publishes original papers on the archaeology, prehistory, and ethnohistory of Latin America, i.e., Mesoamerica, Central America, and South America, together with culturally affiliated adjacent regions. Papers may also treat more general theoretical and methodological issues with relevance to Latin America. Authors submit manuscripts to the editor for consideration as ARTICLES or REPORTS in English, Spanish, or Portuguese. The normal, expected length of an ARTICLE will be 10-15,000 words, including bibliographies and tables. REPORTS should be under 10,000 words. Tables and illustrations should be limited to those that are appropriate and necessary. Authors are required to submit manuscripts electronically through Editorial Manager ${ }^{\mathscr{C}}$ (http://www.editorialmanager.com/laq). Detailed information on policy, style, and technical matters of manuscript preparation is given in English and in Spanish in the "Editorial Policy, Information for Authors, and Style Guide for American Antiquity and Latin American Antiquity," available through the World Wide Web at http://www.saa.org/ Publications/StyleGuide/styframe.html. For additional information, updates, or clarification, consult the managing editor at the SAA office in Washington, D.C.

\section{BOARD OF DIRECTORS OF THE SOCIETY FOR AMERICAN ARCHAEOLOGY}

Officers

President: W. FREDRICK LIMP, RPA, University of Arkansas, 304 JBHT (Hunt Center), Fayetteville, AR 72701

President-Elect: JEFFREY H. ALTSCHUL, RPA, Statistical Research, Inc., PO Box 31865, 6099 E. Speedway Blvd., Tucson, AZ 85751-1865

Secretary: JANET E. LEVY, RPA, UNC at Charlotte, 9201 University City Blvd, Department of Anthropology, Charlotte, NC 28223-0001

Secretary-Elect: CHRISTINA B. RIETH, RPA, New York State Museum, Division of Research and Collections, Cultural Education Center 3122, Albany, New York 12230-0001

Treasurer: ALEX W. BARKER, Director, University of Missouri, Museum of Art \& Archaeology, I Pickard Hall, Columbia, MO 65211-0001

Board Members at-Large

SUZANNE K. FISH, University of Arizona, Arizona State Museum ,Tucson, AZ 85721-0001

EDUARDO GOES NEVES, Museu de Arqueologia e Etnologia, Av. Professor Almeida, Prado, 1466, Sao Paulo 05508-900, Brazil

KELLEY A. HAYS-GILPIN, RPA, Northern Arizona University, 1750 W. Chelsea Way, Flagstaff, AZ 86001-9031

SARAH A. HERR, RPA, Desert Archaeology, Inc., 3975 N. Tucson Blvd, Tucson, AZ 85716-1037

ALSTON V. THOMS, Department of Anthropology, Texas A\&M University, 309J Anthropology Building, 4352 TAMU, College Station, TX 77843-4352

MELINDA ZEDER, Smithsonian Institution, NMNH MRC 112, PO Box 37102, Department of Anthropology, Washington, DC 20013-7012

\section{Ex-Officio Board Member}

TOBI A. BRIMSEK, Executive Director, Society for American Archaeology. 1111 14th Street NW, Suite 800, Washington, DC 20005 


\section{ARTICLES}

3 Concepts of Ethnicity and Culture in Andean Archaeology Emily M. Stovel

21 My State or Yours? Wari "Labor Camps" and the Inka Cult of Viracocha at Raqchi, Cuzco, Peru Bill Sillar, Emily Dean, and Amelia Pérez Trujillo

47 Posthumous Body Manipulation in the Classic Period Mixtequilla: Reevaluating the Human Remains of Ossuary I from El Zapotal, Veracruz

Vera Tiesler, Arturo Romano-Pacheco, Jorge Gómez-Valdés, Annick Daneels

72 An Analysis of pXRF Obsidian Source Attributions from Tikal, Guatemala Hattula Moholy-Nagy, James Meierhoff, Mark Golitko, and Caleb Kestle

\section{REPORT}

98 The Deep Prehistory of Indian Gaming: Possible Late Archaic Period Game Boards at the Tlacuachero Shellmound, Chiapas, Mexico

Barbara Voorhies

\section{REVIEWS}

116 From Foraging to Farming in the Andes: New Perspectives on Food Production and Social Organization, edited by Tom D. Dillehay Mark Aldenderfer

117 Settlement and Subsistence in Early Formative Soconusco: El Varal and the Problem of Inter-Site Assemblage Variation, edited by Richard G. Lesure Robert P. Kruger

119 Ethnicity in Ancient Amazonia: Reconstructing Past Identities from Archaeology, Linguistics, and Ethnohistory, edited by Alf Hornborg and Jonathan D. Hill

John H. Walker

On the cover: Schematic reconstruction of Death God shrine with associated large terracotta statues (redrawn by Belem Ceballos from Wyllie 2008:236, Figure 13). From "Posthumous Body Manipulation in the Classic Period Mixtequilla: Reevaluating the Human Remains of Ossuary I from El Zapotal, Veracruz," by Vera Tiesler, Arturo Romano-Pacheco, Jorge Gómez-Valdés, Annick Daneels, page 49

@ The paper used in this publication meets the requirements of ANSI/NISO Z39.48-1992

(Permanence of Paper). 